The Historical Fournal, 45, 4 (2002), pp. 797-817 C 2002 Cambridge University Press DOI: I0.IOI7/Soor8246X02002686 Printed in the United Kingdom

\title{
ENGLISH RUGBY UNION AND THE FIRST WORLD WAR
}

\author{
TONY GOLLINS \\ De Montfort University
}

\begin{abstract}
The idea that war was a football match writ large was commonly expressed in Britain during the First World War. This article looks at the attitudes and actions of the English Rugby Football Union and its supporters before, during, and after the First World War to examine how such beliefs were utilized by sports organizations and the impact they had on the military and on society as a whole. Rugby union football was viewed both by its supporters and general observers alike as the most enthusiastic and committed sporting supporter of the war effort; the article explores rugby's overtly ideological stance as a means of shedding light on broader discussions about the cultural impact of the war, such as in the works of Paul Fussell and Jay Winter, and about the continued survival of traditional and Edwardian ideas of patriotism among the English middle classes in the immediate post-war period.
\end{abstract}

It was a common experience before I9I4 to read attacks upon the excessive athleticism of the country in general, and of the public schools in particular. Since then the war has come and gone, and the youth of the country has passed through the furnace of trial. In the test of that experience one game at any rate has been justified triumphantly, not only as a pastime, but as an instrument of true education, and that is Rugby football. ${ }^{1}$

That sport is a metaphor for war is a widely acknowledged truism of the last hundred years. And, as many historians have pointed out, the identification of games and military endeavour was at its closest during the First World War. The works of Birley and Veitch in particular have illustrated that during the early years of the conflict the idea that the I9I4-I8 War was a football match writ large was widespread, especially among the middle classes. ${ }^{2}$ However, there has as yet been little exploration of how such beliefs were utilized during and after the war by sporting organizations themselves or through the wider interaction between sport and society. This article seeks to examine the role that rugby union football played in the First World War and the uses made of that experience by its governing body in England, the Rugby Football Union (RFU). Rugby union was viewed both by its supporters and general observers of sport alike as the most enthusiastic and committed sporting supporter of the British war effort; its overtly

1 Times, 26 Feb. I9I9.

2 Derek Birley, 'Sportsmen and the deadly game', British fournal of Sports History, 3 (ig86), pp. 288-3ro; Colin Veitch, 'Play up! play up! and win the war! Football, the nation and the First World War', Journal of Contemporary History, 20 (I985), pp. $3^{6} 3^{-77}$. 
ideological stance allows us to explore wider discussions about the cultural impact of the war, such as those in the works of Fussell and Winter, and about the continuing survival of Edwardian ideas of patriotism among the English middle classes in the immediate post-war period. ${ }^{3}$

The response of the RFU to the outbreak of the First World War was conditioned by the role which it had ascribed to itself in late Victorian and Edwardian society. Rugby had split in two in I895 when the RFU had refused to relax its strict amateurism and allow players to be paid compensation for 'brokentime' - time taken off from work in order to play rugby - as had been demanded by the predominantly working-class clubs in the north of England. These clubs formed the rival Northern Rugby Football Union (NU), which became the Rugby League in I922, but their departure allowed the RFU to develop its game shorn of the threat of commercialism or working-class domination that had been seen in soccer. With the exception of remaining pockets of working-class participation in the south-west and parts of the Midlands, English rugby union was dominated by the professional and managerial classes both on and off the pitch: of 233 men who played for England between I9or and I93 I whose occupations can be traced (out of a total 3 I 3 players) 92 per cent were from social classes I and II on the registrar general's occupational scale. ${ }^{4}$ Moreover, for its supporters rugby union had a higher moral purpose than mere recreation: its goal was to train young men to be leaders of the Empire, to demonstrate the superiority of the Anglo-Saxon race in peace and in war. In the eyes of many it had long been seen as a more than adequate form of military training. Without it, mused B. Fletcher Robinson in I896, Britain would lose its place as Europe's leading nation to those countries that practised conscription. Loretto headmaster H. H. Almond argued that rugby's purpose was to produce 'a race of robust men, with active habits, brisk circulations, manly sympathies and exuberant spirits' who were ready to lead and to follow in defence of the Empire. ${ }^{5}$

Rugby union saw itself as the very embodiment of the late Victorian and Edwardian imperial ideal as practised by the public schools - vigorous, masculine, militaristic, and patriotic. In boys' school stories of the later igoos, one can see an increasing tendency for the sporting hero to be a 'rugger' player and for the violence inherent in the game to be presented in a cathartic, characterforming way. Hugh Walpole's I9I2 novel Prelude to adventure is perhaps the most literarily accomplished example of this genre. His hero, Olva Dune, plays poorly in a game until almost knocked unconscious. The impact renews his enthusiasm: 'Now there was no hesitation or confusion. A vigour like wine filled his body ...

${ }^{3}$ Paul Fussell, The Great War and modern memory (London, 1975). Jay Winter, Sites of memory, sites of mourning: the Great War in European cultural history (Cambridge, I998). For a recent discussion see Niall Ferguson, The pity of war (London, I998), pp. 448-57.

4 Tony Collins, Rugby's great split (London, I998). Social class statistics are from Eric Dunning and Kenneth Sheard, Barbarians, gentlemen and players (New York, I979), p. 237.

${ }^{5}$ B. Fletcher Robinson, Rugby football (London, I896), p. 50; H. H. Almond in Reverend Frank Marshall, ed., Football: the rugby union game (London, I892), p. 55. 
he was amazing. He was everywhere ... For such a man as he there should only be air, love, motion, the begetting of children, the surprising splendour of a sudden death.'

The link between violent death and rugby was expressed in an even more zealous fashion by the Dulwich College school song: 'fifteen fellows fighting full, out for death or glory'. ${ }^{6}$ As David Cannadine and others have noted, this belief in the glory of death in battle was widespread in public school literature of the period. ${ }^{7}$ Henry Newbolt's Vitai Lampada, with its rallying call to 'Play up! Play up! and play the game', and Poet Laureate Alfred Austin's cry of 'who would not die for England!... Duty and Death that evermore were twin' set the tone for the era. ${ }^{8}$ The importance of the warrior hero in the Greek classics was transplanted to an England which felt threatened abroad and was troubled by self-doubt at home. Military death for young males was viewed as ennobling, something to be welcomed in the service of one's country. H. A. Vachell's I905 The hill presented this in the starkest possible way: 'To die young, clean, ardent; to die swiftly in perfect health; to die saving others from death, or worse - disgrace - to die scaling heights ... is not that cause for joy rather than sorrow? ${ }^{\prime 9}$

In the decade before the war, the leadership of the RFU attempted to place itself in the forefront of this militaristic, patriotic ideology by seeking to increase the number of public schools playing its sport and by launching a determined effort to establish itself as a major sport with the armed services. Initially, however, the Army did not share the RFU's belief in the military importance of rugby. Soccer was the Services' game and such was its popularity that in 1906 there were 578 soccer teams in the Army and I8o in the Royal Navy, against a mere handful of rugby union sides. ${ }^{10}$ It was only in that year that the RFU took steps to develop their sport in the armed forces, with an Army cup tournament for regimental teams and the first match between the Army and the Royal Navy, although this was restricted to officers. The growth of rugby in the forces was also helped by the creation, again in Igo6, of the Amateur Football Association, which split the ranks of middle-class soccer clubs. Although the Army FA stayed loyal to the established FA, the rupture allowed the RFU to stake a claim to be the one national football body truly committed to the amateur ethos and it steadily grew in strength up to I9I ${ }^{11}$

${ }^{6}$ Walpole story reprinted in Howard Marshall, ed., Rugger stories (London, I932), p. 24I. Dulwich school song in Geoffrey Best, 'Militarism and the Victorian public school', in M.J. Bradley and B. Simon, eds., The Victorian public school (London, I975), p. I42.

7 David Cannadine, 'War and death, grief and mourning in modern Britain', in J. Whaley, ed., Mirrors of mortality: studies in the social history of death (London, I98I), p. I95. See also Peter Parker, The old lie: the Great War and the public school ethos (London, I987), and J. A. Mangan, Athleticism in the Victorian and Edwardian public school (Cambridge, I98I), and his The games ethic and imperialism (London, I986).

8 Austin in James Morris, Pax Britannica: the climax of an empire (London, Folio edition, I992), pp. 75-6.

9 H. A. Vachell, The hill (London, I905), p. 236.

10 FA Council minutes, I2 Mar. I906.

11 Torkshire Post, 23 Oct. I9o6. 
Paradoxically, the impact of international tours to Britain by New Zealand in I905 and South Africa in I9o6 added weight to rugby's claims of imperial importance, despite the heavy defeats usually experienced by the home nations. ${ }^{12}$ In the midst of much concern over the physical fitness of Britain following the Boer War, the failures of the England team - between I895 and I9Io it won just twelve of its forty-eight first-class international matches - appeared to add weight to the widespread belief that the nation was in physical decline. In contrast, the skills, athleticism, and success of the colonial tourists seemed to demonstrate how rugby could help to develop a healthy, masculine nation. However, it is worth noting that such were the socially myopic views of commentators of the time that no one pointed out that England drew its players almost entirely from the middle classes, following the split with the northern clubs, whereas the New Zealand touring side, not to mention the Wales team that inflicted the only defeat on them in I905, included members both of the professions and of the industrial working classes. In a comment typical of the time P. A. Vaile, writing a year after the publication of the 1904 Report of the Interdepartmental Committee on Physical Deterioration, went so far as to claim that rugby was the 'best trial of the relative vigour and virility of any two or more opposing countries'. ${ }^{13}$

Such sentiments were not mere observations; as fears of a European war grew in the years immediately before I9I4, many rugby union clubs such as Harlequins, Blackheath, and London Scottish developed close links with the Territorial Army. Indeed, one of the reasons many English rugby union players joined the Army so quickly in August I9I4 was that they were already in the Territorial Army or had been trained in the Officer Training Corps at school or university. Both Adrian Stoop and Ronald Poulton, successive Harlequins and England captains and players who were the supreme embodiment of the dashing rugby back, were keen Territorial officers. Poulton had joined the Officer Training Corps in his first year at Oxford in 1908 and declared himself to be 'frightfully keen on soldiering'. ${ }^{14}$ In Ulster the link between the sport and the military was even more apparent; the I9I3-I4 season had been abandoned because the vast majority of players had joined Edward Carson's Ulster Volunteer Force. When the war finally came it was regarded, in the words of a follower of rugby union writing in I9I9, as 'the game for which they had been preparing for so many years' ${ }^{15}$

\footnotetext{
12 Indeed, the England team did not defeat a touring national side until 1936 and subsequently managed just two more such victories before the RFU's Centenary in I97I.

13 Times, ro Oct. I905. See also John Nauright, 'Colonial manhood and imperial race virility: British responses to post-Boer War colonial rugby tours', in John Nauright and Timothy Chandler, eds., Making men: rugby and masculine identity (London, I996).

${ }_{14}$ Quoted in Edward Bagnall Poulton, The life of Ronald Poulton (London, I9I9), p. I45.

15 Times, 4 Mar. igig.
} 
Although there is some truth in the idea that at the declaration of war rugby union immediately closed down for the duration, the reality was not quite so straightforward. Initially, the RFU believed that the season should continue. As soon as war was declared, it found itself inundated with requests for guidance

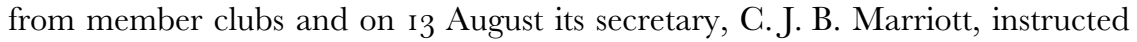
clubs to carry on playing where possible:

I have consulted my emergency committee, and they feel that they must leave it to those clubs that have sufficient players left to do as they think best with regard to carrying out their programme, but are of the opinion that it will be advisable to do so where clubs can. The committee of the Prince of Wales Fund expressed a hope that a portion of the gates may be devoted to that fund, and the English Rugby Union hopes clubs will approve the suggestion. ${ }^{16}$

But hopes of a continuation of the season were already melting away as players flocked to the colours. Ronald Poulton seemed to speak for most players when he wrote to his parents in August I9I4 that 'Germany has to be smashed, i.e. I mean the military party, and everybody realises, and everybody is volunteering. And those who are best trained are most wanted, and so I should be a skunk to hold back. ${ }^{, 17}$ Clubs with strong military links found themselves unable to raise teams within the first week of the crisis. Old boys' clubs such as Haileyburians and Leysians announced they were cancelling all fixtures because 'practically every' player had enlisted. ${ }^{18}$ Despite an initial belief that they could continue because 'their membership is scholastic rather than military', London Irish cancelled their season in mid-September. ${ }^{19}$ Moseley voted to cancel all fixtures and offered their ground to the military authorities. ${ }^{20}$ At Harlequins' annual general meeting most members turned up in khaki to demonstrate their commitment to the greater game and voted $£ 500$ to national war funds. ${ }^{21}$ Of the ior members of the Old Alleynians club, comprised of former pupils of Dulwich College, the school magazine reported that 'all are serving in H. M. Forces, with the exception of twenty-one, of whom eight are Government servants, three are under seventeen years of age, two have defective eyesight, three are not British subjects, and the remaining five are prevented from joining owing to special circumstances' ${ }^{22}$

In the north, Birkenhead Park reported that they would not be able to fulfil any fixtures because 'our entire first XV, and practically all the remainder of our playing members, are in some service or another, and our ground is also being used'. ${ }^{23}$ Liverpool declared that seventy members had joined up; New Brighton seventy-five, Sunderland eighty-nine, and the Vale of Lune 'fifty or sixty'. The Cumberland county committee's belief that county representative games could

16 Athletic News, 24 Aug. I914.

17 Letter of 28 Aug. I9I4, reprinted in Poulton, Life of Ronald Poulton, p. 308.

18 Times, 9 Sept. I9I4.

${ }^{20}$ Athletic News, i4 Sept. I9I4.

22 The Alleynian, Mar. I9I5.

19 Athletic Newes, io Aug. I9I4; Times, 2i Sept. I9I4.

21 Ibid., 2 I Sept. I9I4.

23 Athletic News, 24 Aug. I9I4. 
continue was undermined within days by mass enlistment. ${ }^{24}$ Walter Roberts of Harrogate Old Boys' club commented that 'the feeling is very strong that football should be suspended for the season. Most of our boys have joined the 'Terriers' [Territorial Army] or applied for commissions. ${ }^{\mathbf{2 5}}$

However, this response was not entirely uniform throughout English rugby union. In Devon, where the game retained a significant following among the working class, especially in Plymouth and Torquay, a special conference of the county's rugby union had initially decided to follow the example of the Football League and the Northern Union and continue playing after the declaration of war. Despite this willingness to continue, clubs in the region quickly found that the clamour to volunteer and the increase in working hours for dockyard workers meant that organizing fixtures became virtually impossible and the season was abandoned. ${ }^{26}$ By the beginning of September club rugby union throughout England was at an end.

On 4 September, in recognition of this accomplished fact, the RFU Committee formally cancelled all club, county, and international matches. In south Wales, where rugby had a much wider social basis of support and was the principal sport not only of the middle classes but also of the industrial working classes, the Welsh union followed the lead of the RFU and immediately suspended all matches for the duration of the war. Although the Scottish Football Union, as the game's governing body in Scotland was then known, had initially left the matter in the hands of 'the good sense of each club', in the belief that 'a game of football on a Saturday afternoon will in all ways be desirable and advisable, so long as national duties are not interfered with', the rapidity with which their players enlisted meant that the Scottish rugby season also came to a premature end within the first few days of September. ${ }^{27}$

At its 4 September meeting the RFU also called upon all its players aged between nineteen and thirty-five to enlist and for the formation of a rugby players' battalion. However, after discussions with the War Office, G. J. B. Marriott told the clubs that 'it is not feasible to form a separate battalion of Rugby men', but that 'various commanding officers ... will gladly accept for their Regiments a company (about I20) of Rugby men who could be enlisted together'. He then asked volunteers to send their particulars directly to him. ${ }^{28}$ In fact, the prospect of a national battalion had already been scuppered by the rush to join local regiments. Former RFU secretary Rowland Hill was one of many rugby administrators who reflected this trend when, a few days before Marriott's circular, he appealed to clubs in Kent to 'encourage their members to join the Second Battalion now being formed of the Twentieth London (Blackheath). Clubs and leagues coming forward in sufficient numbers will form a company, or

${ }^{24}$ Ibid., 3I Aug. I9I4. $\quad{ }^{25}$ Torkshire Post, I Sept. I9I4. $\quad{ }^{26}$ Athletic Newes, 24 Aug. I9I4.

${ }^{27}$ RFU Committee minutes, 4 Sept. I9I4. For Wales, see David Smith and Gareth Williams, Fields of praise (Cardiff, I980), pp. 20I-3. For Scotland, see Times, I3 Aug. I9I4.

28 Marriott's circular is in the Yorkshire Rugby Football Union commemoration book, p. 266. 
section, which will allow friends to soldier with one another. ${ }^{29}$ This enlistment of players together in local regiments was part of the same process which led to the formation of Pals' Battalions from late August onwards. Credited as being the brainchild of Lord Derby, the Pals' Battalions were initially formed by members of local middle classes as a way of serving together with their social equals. ${ }^{30}$

But for many in rugby union, enlisting was not enough. The imperial mission which the sport ascribed to itself led some in the game to appoint themselves as unofficial recruiters. The Yorkshire Rugby Union (YRU) called on its clubs to approach non-enlisted youths under nineteen and men over thirty-five 'with the object of forming a company in connection with your club, for the purposes of drilling and training in rifle practice', and warning that 'no excuse ought to be tolerated for his non-compliance'. This was too much even for some of the YRU's supporters, one of whom complained that the creation 'of various corps of "armed civilians" all over the place ... are of more real danger to their country than they could ever be worth' and the plan was quietly forgotten. ${ }^{31}$ Others devoted considerable energy to recruit volunteers, notably Leicester club secretary Tom Crumbie who used the Welford Road ground as an enlistment centre to recruit 3,500 men in the East Midlands to the forces. ${ }^{32}$ Perhaps the most famous example was that of RFU committee member Edgar Mobbs. Mobbs had been a dashing three-quarter for England and when war was declared he immediately volunteered but was unable to enlist as an officer because at thirty-two he was considered too old. Undeterred, he enlisted as a private and set about raising his own corps in Northamptonshire. In three days he recruited 250 men who became the Seventh (Service) Battalion of the Northamptonshire Regiment. ${ }^{33}$

Rugby union spokesmen were also at the forefront of those who clamoured for all sport to cease for the duration of the war. Rowland Hill claimed that by allowing soccer to continue, the FA Council 'had allowed one of the greatest sports in the world to be solely and entirely governed by commercial principles' ${ }^{34}$ Leading YRU official James Miller felt that 'playing fields were being desecrated at the present time' and that 'it was necessary to compel those who idled around the streets - those shirkers and bullet-funkers - to join the ranks, ${ }^{35}$ The references to shirkers indicated the underlying class prejudice that lay beneath much of this criticism and Miller had little hesitation in pointing an accusing finger at 'members of other football bodies [who] had not responded in a like manner. It seems to me that a hot blush of crimson must come into the faces of

29 Times, 4 Sept. I9I4. $\quad{ }^{30}$ Peter Simkins, Kitchener's army (Manchester, I988), pp. 79-103.

31 YRU statement of 9 Sept. I9I9 in the Yorkshire Rugby Football Union commemoration book, p. 267. Letter in Athletic News, 28 Sept. I9I4.

32 Athletic News, 27 Nov. I9I6; David Hands, Leicester F. C., I88o-I98o (Leicester, I98I), p. 33.

${ }^{33}$ Athletic Newes, 26 Oct. I9I4; Captain Guy Paget, History of the raising of the 7th (Service) Battalion, Northamptonshire Regiment (Aldershot, I9I5); H. B. King, 7th (S) Battalion Northamptonshire Regiment, I9I4I9I9 (Aldershot, I9I9); S. J. Edwards, Sportsman and soldier (privately published by the author, I998).

${ }^{34}$ Athletic News, I4 Dec. I9I4.

35 Torkshire Post, i Sept. I9I4. 
those footballers who remained at play when others went abroad to fight their battles for them. ${ }^{, 36}$

Nevertheless, despite its suspension at a club level, rugby union quickly reappeared in a military guise. Matches began to be organized almost as soon as the first volunteers arrived in training camps: a typical example being the Eighth Battalion of the East Surrey Regiment whose team met the Seventh Battalion of the West Kent Regiment while undergoing basic training at Purfleet. The Surreys won $37-3$ thanks to a side which included five Welsh internationals and a Cambridge Blue. Inter-platoon tournaments played by battalions in training camp were commonplace. Games were also regularly arranged between battalions and nearby schools; for example, in late September I9I4 Lancaster Royal Grammar School played host to a team from the Fifth (Reserve) Battalion of the Royal Lancasters. ${ }^{37}$ On $3{ }^{\text {I }}$ October I9I4 a match advertised as being between England and Wales was played between soldiers at Shoreham Camp in Sussex. In the north of England, a match was arranged at Doncaster between two regimental teams in the presence of the town's mayor; the sides included two internationals and seven county players. In early November, Leicester saw a Northern Command team defeated $3^{8-} 3$ by a team selected by Tom Crumbie. ${ }^{38}$

Despite its leaders condemning the professional codes of football, military rugby union became a significant wartime spectator sport. In early December, in what was to establish a pattern of regular matches in London, the Public Schools and Universities Battalion narrowly defeated a Canadian military side in front of 3,ooo spectators at the Richmond Athletic ground. The sizes of the crowds which were being attracted to such games were potentially embarrassing to rugby union. The national campaign against 'shirkers' who preferred to watch football rather than enlist was at an hysterical pitch and there was a certain coyness in newspaper reports about the success of such games. The Times's reporter did not mention the size of the crowd but focused on 'the ring seats along the touchline presented the appearance of being almost solidly military - rows and rows of khaki caps and khaki figures leaning forward with hands on knees, rows of canes waving in time to the tunes or war cries that rose and fell' ${ }^{39}$ The contrast with the supposed crowds of 'loafers' attending soccer matches could not be made clearer even a year later, when much of the hysteria had died down, rugby union correspondents were still seeking to emphasize the difference: "the "shirker" does not patronise rugby union matches. He is not wanted at them', declared W.L.S. in Athletic News. ${ }^{\mathbf{4 0}}$

Even so, major matches continued to attract significant attendances. On New Year's Day i9I5, 20,000 saw the Canadians play at Leicester, one of four games

\footnotetext{
36 Ibid., I5 Sept. I9I4.

37 Ruth Elwyn Harris, Billie: the Nevill letters, I9I4-I9I6 (London, I99I), p. I9; Laurie Milner, Leeds pals (London, I99I), pp. 58-9; Torkshire Post, i Oct. I9I4.

${ }^{38}$ Times, 30 Oct. I9I4; Yorkshire Post, I4 Nov. I9I4; Athletic News, 9 Nov. I9I4.

39 Times, I4 Dec. I9I4; Yorkshire Post, I4 Dec. I9I4.

40 Athletic News, 22 Nov. I9I5.
} 
played there over the Christmas and New Year's holidays. An August I9I5 tournament at Northampton between English and Scots military sides attracted over 8,ooo spectators. As well as garnering sizeable attendances, the first few weeks of I9I5 saw something like a structured season develop for military rugby teams. Athletic Newes noted that there were at least ten military sides in London looking for regular fixtures. One such team was 'the Third Battalion of the Honourable Artillery Company, who are pleasantly quartered at Mount Felix, Walton on Thames, [and who] would be glad to arrange Rugby matches with regimental teams on Saturdays at home or away'. ${ }^{41}$

However, the war effort's ceaseless appetite for men meant that by September I9I5 the new domestic season had fewer teams and fewer players, although the game was now being played by the services overseas. The first reported overseas game seems to have been that played by teams from an interned Naval Brigade at Groningen in Holland which included the Oxford half-back A. C. Williamson. Rochdale's international Northern Union winger Jack Robinson, who was badly wounded at Neuve Chappelle in March 1915, reported playing rugby during the battle, saying that 'our boys out yonder will have their game of football under all sorts of conditions. It comes as a tonic and a relaxation from trench duty and I cannot understand anybody in England ever questioning the advisability of the game.' Before the Battle of Loos in September of I9I5 the Gordons played the Queen's Own Cameron Highlanders, while in the following year the commanding officer of the Thirteenth Battalion of the Rifle Brigade broke his collar bone in an Officers versus Other Ranks rugby match the day before the Battle of the Somme. Ronald Poulton's last rugby match was played in Belgium in I9I5 when he captained the South Midland Division (Forty-Eighth) versus the Fourth Division. The poet Robert Graves also turned out as a full back for the First Battalion of the Royal Welch Fusiliers in a match in France. ${ }^{42}$ However, these games were organized on an ad hoc basis; there were no formal interregimental or battalion rugby competitions in the field, as became the case for soccer later in the war.

In fact, rugby of whatever code occupied a distant second place compared to the popularity of soccer with troops on active service. As a correspondent of The Times later lamented,

it is strange that the game was so little played in France during the war. There was never any difficulty raising sides to play Association, and there was scarcely a squadron, cavalry, engineers or signallers, or a platoon that did not possess its own team and its own wonderfully coloured jersey. Yet Rugby games were few and far between. ${ }^{43}$

${ }^{41}$ Ibid., II Jan. and I Feb. I915.

42 Ibid., I8 Jan. and 18 Oct. I9I5; Edmund McCabe, 'Rugby and the Great War', Stand To!, 52 (1998), pp. 41-4; Lyn Macdonald, Somme (London, I983), p. 319; Poulton, Life of Ronald Poulton, p. 3II; Robert Graves, Goodbye to all that (rev. edn, London, I960), p. I49.

${ }_{43}$ Times, 4 Mar. I9I9. 
The war diary of Huddersfield and England Northern Union rugby forward Douglas Clark for 1917 describes a number of soccer matches of varying degrees of formality in which he played while in France but only one game of rugby. ${ }^{44}$ The danger of injury and the difficulty of playing rugby on an improvised pitch naturally gave the round ball game an inbuilt advantage.

But soccer's popularity was based on more than its playing. As J. G. Fuller has noted, army soccer was a 'practical exercise in class collaboration', a sport which men of all ranks could play and which helped to cement esprit de corps among the troops. ${ }^{45}$ Outside of those from rugby-playing regions in northern England, south Wales, or to a lesser extent the Scottish borders, rugby was generally viewed by officers and men alike as a game almost exclusively for officers: soccer was the sport of the ranks. Paul Jones, the former captain of the Dulwich College first XV, wrote home from France in October I9I5 that 'the Tommies - the English ones, at least - think soccer the only game, so one must cut one's cloth to one's opportunities ${ }^{46}{ }^{46}$ It is noticeable that in R. C. Sheriff's 1927 play Fourney's end the protagonists play soccer at the front, despite being rugby players at home. Nor was it an accident that it was soccer balls which were kicked by rugby-playing officers into no man's land for troops to follow when going 'over the top'. Although it was later claimed that both Edgar Mobbs's brigade and the I6th Battalion of the Northumberland Fusiliers had kicked a rugby ball out of the trenches, there is no available contemporary evidence to show that either of these events occurred. ${ }^{47}$

Regardless of its failure to rival soccer's popularity in the Army, the beginning of ${ }_{191} 6$ saw rugby union enter what, were it not for the circumstances of its playing, could be termed a golden age of domestic competition. The introduction of the 'Derby Scheme' in IgI6 - which brought in many professional Northern Union rugby players who had not already volunteered - and the huge influx of troops from Australia, New Zealand, and South Africa greatly expanded the pool of players available to military rugby union sides. The number of games played rose dramatically - for example, between March and April ı1ı6, The Times carried results from twenty-two matches, mainly played between teams from the Dominions and the south of England, including services teams such as the Royal Military Academy, the Royal Flying Corps, the Welsh Guards, and the Artists' Rifles. Many of the London hospital teams continued to play regularly too. Crowds of 7,000 or 8,00o people were not exceptional for matches involving the Dominions teams. The enthusiasm for quasi-international matches was so great that in February I9I7 it was announced that a crack team of New Zealanders

${ }^{44}$ Douglas Clark MS diary, Imperial War Museum, 90/21/I; Athletic Newes, 23 Dec. 1918 and 22 Feb. 1915.

${ }^{45}$ J. G. Fuller, 'Popular culture and troop morale in the British and Dominion forces, $1914-1918$ ' (DPhil thesis, Cambridge, I988), p. I27.

${ }^{46}$ Paul Jones, War letters of a public school boy (London, I918), p. I57.

${ }^{47}$ John Maclaren, The history of army rugby (Aldershot, 1986), p. 83. For more on the kicking of footballs into no man's land, see Fussell, The Great War, pp. 27-8. 
serving on the Western Front was to tour southern England as the New Zealand Trench Team. The Times reported that ticket applications for their matches were already being taken, but within days of its announcement the tour was cancelled, no doubt because of disquiet about soldiers being withdrawn from the front merely to play rugby. ${ }^{48}$ The spirit in which these games were played was never less than competitive, so much so that in 1918 the London Society of Referees refused to officiate in any further matches involving the Welsh Guards because of their 'foul play' - such was the scandal that the regiment immediately disbanded the team. Nor was it free of monetary consideration; later that same season an Australian army side demanded $£ 6$ o to play the Yorkshire county side. ${ }^{49}$

IgI 6 also saw a revival of rugby union in the north of England. The first major match in the north since I9I4 took place between a 'North of England Military Team' and an Australasian representative side in Leeds in April I9ı6, with the sides boasting four leading professional NU players each. Although this was not the first time that NU players had played rugby union during the war - Wigan's Gwyn Thomas had turned out for the Barbarians against South Africa in November 1915 - the prominence of the players involved called into question the RFU's policy of forbidding NU players from playing rugby union. Since the I895 split, the RFU had barred all NU players from playing its game and banned for life any rugby union player who played NU rugby, regardless of whether they had been paid to do so. At the start of the $1916-17$ season, the ban was further undermined when Major R. V. Stanley, the Oxford University representative on the RFU committee, unveiled his Army Service Corps (Motor Transport) team at Grove Park in south London. ${ }^{50}$ It included Huddersfield's international NU players Harold Wagstaff, Douglas Clark, Ben Gronow, and Albert Rosenfeld, together with three other star NU players, and was defeated once in twenty-six games that season. ${ }^{51}$ The Devonport Royal Navy depot assembled a similar side which eventually included nine NU players, of whom four were internationals. The fact that so many rugby union officials had included NU men in their sides meant that the RFU had to act simply to maintain control of the situation. On 4 October ${ }^{9} 96$ it issued a statement to clarify its position: 'Northern Union players can only play with Rugby Union players in bona-fide naval and military teams. Rugby Union teams can play against naval and military teams in which there are Northern Union players. Munitions workers cannot be regarded as naval and military players. These rulings only obtain during the war. ${ }^{52}$

This was not so much a concession as a recognition of the new status quo. It allowed the RFU to pose as a supporter of national unity while at the same time signalling its intention to continue as an exclusive organization as soon as hostilities ceased. Nor was its exclusion of munitions workers from the edict

48 Torkshire Post, Io Feb. I917; Times, I2 and I5 Feb. I917.

49 A. J. Trollope, secretary of the London Society, in Times, 30 Nov. I918; Athletic Neres, 3 Dec. 1918; Yorkshire Post, io Feb. I919.

${ }^{50}$ Athletic Newes, 27 Dec. I915. $\quad{ }^{51}$ Ibid., I6 Apr. I917. $\quad{ }^{52}$ Times, 5 Oct. Igi6. 
surprising - the prominent rugby union writer E. H. D. Sewell undoubtedly spoke for many in the sport when in I9I5 he hoped that soccer would 'remain the exercise of the munitions workers who suffer so much from varicose veins, weak knees, cod-eyed toes, fowl's livers and a general dislike for a man's duty'. ${ }^{53}$

Indeed, the central leadership of the RFU pulled up the gangway between the two codes of rugby as soon as the opportunity arose. On I4 January I9I9, at its first committee meeting since September I9I4, the RFU declared that NU players could only play rugby union in the services if they did not also play NU rugby. ${ }^{54}$ Outside of the RFU Committee, this stance was not without opposition. Welsh rugby union president Horace Lyne had written to the RFU suggesting that 'Northern Union players who had been on active service' should be eligible for reinstatement as amateurs but his proposal found no support at the meeting. ${ }^{55}$ Determined not to compromise, the RFU tightened its restrictions again in April I9I9 when it announced that 'civilian clubs are not permitted to play against Service teams containing NU players ${ }^{56}$ The May igrg Committee meeting saw a series of appeals for reinstatement from players in Devon who had been banned for professionalism in 1913, all of which were met with the laconic response: 'Declined' ${ }^{57}$ Those leading the RFU saw the war as a vindication of their prewar policy of rigorous amateurism rather than a cause for change: 'moderation is impossible' was how one supporter described their position. ${ }^{58}$ The prestige which it had gained during the war and its close identification with the war effort easily allowed the RFU to brush aside the reformers in its ranks.

\section{I}

It was an authority that had been secured with blood. The England side lost twenty-seven internationals. Bristol, with a broader social base than most teams, lost 300 members; forty-five of the sixty players in London Scottish's four pre-war teams were killed; Richmond lost seventy-three members, Rosslyn Park seventytwo, Liverpool fifty-seven, Hartlepool thirty-three; of the Old Merchant Taylors' I9I4 first team thirteen were killed and two permanently disabled; these are just some of the more prominent examples. Scottish rugby union, with a social basis similar to that of the English game, lost thirty international players. In contrast, Wales lost eleven internationals, possibly a consequence of its much broader working-class base which reduced the opportunities for middle-class players, who were statistically those most likely to be killed, to appear in the national side. Surveying the carnage that had been visited upon English rugby a few weeks after the armistice, a correspondent in The Times wrote without a hint of irony that 'of the English fifteen which played before the King at Twickenham early in I9I4, scarcely one is left; they might indeed on that occasion have hailed

${ }^{53}$ Sheffield Star Sports Special, i6 Oct. I9I5.
${ }_{55}$ Ibid.
${ }^{57}$ RFU Committee minutes, 26 May i9i9.
54 RFU Committee minutes, I4 Jan. I9I9.

56 Times, I5 Apr. I9I9.

58 Athletic News, I6 Oct. I9I7. 
their distinguished spectator, only too appropriately, with the ancient gladiators' cry, "Morituri te salutant". ${ }^{59}$

This harrowing toll of lost lives flowed directly from the conception that rugby was a preparation for war. The violent, physical nature of the game meant that it was the sport that lent itself most naturally to the vocabulary of war. Lord Jellicoe, admiral and first sea lord during the war, wrote that 'Rugby football, to my mind, above all games is one which develops the qualities which go to make good fighting men. It teaches unselfishness, esprit de corps, quickness of decision, and keeps fit those engaged in it. ${ }^{90}$ In January 1915 the Spectator used rugby to explain the subtleties of trench warfare:

The situation is not unlike that in the 'scrum' in Rugby football. Looked at superficially, almost total immobility seems to have been secured by the contending forces. If, however, one looks closer, there is seen to be a trend in one direction, and if this trend is not checked one knows that the unstable equilibrium will break up, with advantage to the side which is pushing just a little harder than the other.

Nor did the use of rugby as a metaphor disappear when the full horror of the war became apparent. The return to England of two of the soccer balls kicked into no-man's land by the Eighth Battalion of the East Surrey Regiment was greeted by the depot's commanding officer, Colonel Treeby, in the language of rugby: 'our men have played and are playing the game. We are still in the scrum, it is true, but the ball is being carried forward, and we doubt not that in God's good providence the goal for which we are fighting - the goal of freedom, justice and lasting peace - will soon be won. ${ }^{61}$ The most overwrought use of rugby as military metaphor was to be found in a speech of Major-General Sir C. H. Harrington given in April IgIg after a New Zealand services side had defeated a French XV at Twickenham, in which he ascribed the Allies' victory to:

the captaincy of that great soldier Marshal Foch, who developed his attacks so splendidly by means of those loyal and unselfish three-quarter backs, Sir Douglas Haig, General Pershing and the King of the Belgians, and those grand attacking forwards, our respective army commanders. Nor must we forget those wing three-quarters in distant theatres namely our commanders in Egypt, Macedonia, Mesopotamia, Italy and Russia, where our forces all helped so much to increase the score. Behind all we had that sound full-back, represented by the men and women of the allied nations. ${ }^{62}$

The response of those in the front line was more ambiguous. Some soldiers quickly realized that the war was not at all a 'great game'. In December I9I4 Leicester forward W. Dalby wrote home describing an attack on his trench: 'On one occasion all but one German [attacking the trench] turned and fled, and he came on shouting, "Me no done for," but he was a second later. It is nice to read of these things, but not so nice to be in it. We had this sort of thing for four nights

59 Times, 30 Dec. I9i8.

60 Letter of Jellicoe reprinted in E. H. D. Sewell, The log of a sportsman (London, I923), p. I64.

61 Quoted in Harris, Billie, p. 203.

62 Times, 2i Apr. igig. 
and lost half the men in that time. ${ }^{, 63}$ Ted Butcher, a Devon county representative player and long-serving RFU committee member who was one of a handful of surviving officers in Edgar Mobbs's battalion of the Northamptonshire Regiment, suffered from nightmares about the war throughout his life. ${ }^{64}$ There is also evidence that some soldiers actively disliked the use of sporting metaphors: "we didn't dribble footballs, neither did we say "This way to Berlin, boys" nor any of the phrases employed weekly in the News of the World', wrote Roland Mountfort, a survivor of the first day of the Somme. The same dismissals can be found in the magazines produced at the front such as the Wipers Times. ${ }^{\mathbf{6 5}}$

Even so, many other soldiers did believe in the rhetoric of their generals and the propagandists on the Home Front. The letters of Billie Nevill, a keen rugby player at Dover College who helped organize and lead the East Surrey Regiment's football-led attack on German lines at the Somme, are full of the gung-ho spirit to be found in the boy's stories of the Edwardian age: 'war is the greatest fun imaginable', he wrote home at one point. ${ }^{\mathbf{6 6}}$ England international Jack King wrote in his last letter home before being killed in August I9I6 that 'so long as I don't disgrace the old Rugby game, I don't think I mind ' ${ }^{67}$ Eleven months before he was killed in action, rugger-loving Paul Jones of Dulwich wrote that 'in my heart and soul I have always longed for the rough and tumble of war as for a football match' ${ }^{68}$

Indeed, this was where the true value of rugby union lay. Its real claim to occupy a special position in British sporting culture was not due to the military brilliance or the tactical astuteness of rugby-playing officers - it lay in their spirit of sacrifice, their willingness to die for their country. Within days of war being declared, Blackheath announced that they were 'immensely proud of the fact that in the list of wounded in the first engagement of the war in which the British Army was concerned' was one of their players, Lieutenant A. A. M. Durand of the Royal Field Artillery. ${ }^{69}$ As the war drew on, the continual recital of rugby union players who had been killed in combat became a source of pride and it became an accepted truth within the game that it had lost a higher proportion of its players than any other sport. ${ }^{\mathbf{7 0}}$

When the available records are analysed, however, the validity of this claim is not so clear. Of the I6o England internationals who are known to have served in the forces in the First World War, twenty-seven were killed and another died shortly after due partly to wounds received during the war (I6.9 per cent of the total) and twenty-eight (I7.5 per cent) were awarded the Military Cross. Based on

\footnotetext{
63 Athletic News, 2i Dec. I9I4. $\quad{ }^{64}$ Anne Pallant, A sporting century (Plymouth, I997), p. I44.

65 Quoted in Modris Eksteins, Rites of spring: the Great War and the birth of the modern age (London, I989), p. I24; The Wipers Times: a facsimile reprint of the trench magazines, London, I9I8, and J. G. Fuller, Popular culture, passim.

${ }^{66}$ Harris, Billie, p. 7.

${ }^{67}$ Quoted in Yorkshire Rugby Football Union commemoration book, p. 20. For the widespread use of sporting metaphors by troops see Fuller, Popular culture, p. 202.
68 Jones, War letters, p. I98.
69 Athletic News, 7 Sept. I9I4.
70 Times, 26 Feb. I9I9. 
the not unreasonable assumption that the overwhelming majority of those England players serving were officers, we can compare these figures with those for officers in all services as a whole, of whom I3. 6 per cent were killed and I6 per cent were awarded the Military Cross. Given such a small sample, it could be argued that the difference of less than three percentage points is statistically insignificant. These mortality figures are also lower than those of Oxford and Cambridge graduates, who recorded death rates of 19.2 per cent and i 8 per cent respectively. ${ }^{71}$

How do rugby union's figures compare with the other football codes? Here the data is even less reliable, making any meaningful comparison impossible. Neither the Football League nor the Northern Union kept or produced comprehensive lists of players' war records or decorations. The only information available is that relating to fifteen of the twenty-five professional NU clubs published by Athletic News in I9I9. Of 760 players who served in the armed forces, I03 lost their lives, I3.5 per cent of the total. ${ }^{72}$ The limited statistical evidence available means that it is difficult to draw any firm conclusions. It is possible that rugby union players as a whole did suffer a higher casualty rate than other footballers but, given the overwhelmingly middle-class composition of the sport, this was due to social and demographic factors rather than the intrinsic nature of the game. Enlistment rates for the middle classes were higher than those for working-class males, many of whom failed military fitness tests or were engaged in munitions work. Casualty rates for officers were significantly higher than for the lower ranks, which, because entry to the officer class was restricted to those with a public school or university background until the latter stages of the war, meant that a higher percentage of middle-class soldiers were killed. And the fact that many rugby union players were junior officers also meant that they were more likely to play a front-line role leading men into battle - in the first year of the war one in seven junior army officers were killed in contrast to one in seventeen of the ranks. ${ }^{73}$ Given such factors, it does not seem unreasonable to claim, as did one of the sport's supporters in I9I8, that 'those who loved the game were just the type of men to be the first to volunteer, the earliest to be trained, and, from their very keenness and fitness, the quickest "over the top" - the most likely to be killed'. ${ }^{74}$

The huge toll of young lives lost does not appear to have caused anyone involved in rugby union to question the war, with the sole exception of former Scotland captain John MacCallum, a doctor who in I9i 6 refused to serve and attempted to register as a conscientious objector. ${ }^{75}$ Indeed, the opposite is true: its

${ }^{71}$ J. M. Winter The Great War and the British people (London, I986), pp. 7I-93. England players' war records compiled from U. A. Titley and A. R. McWhirter, Centenary history of the RFU(London, I970), and R. Maule, The complete who's who of England rugby union internationals (Derby, I992). I am indebted to Dr Gwyn Prescott for his valuable insights on this section.

${ }^{72}$ Athletic News, io and i7 Mar. 1919. The Football League lost forty-four players; Simon Inglis, League football and the men who made it (London, I988), p. Ioo.

${ }^{73}$ J. M. Winter, 'Upper class casualties', London Review of Books, 5 Mar. I987.

74 Times, 30 Dec. I9I8. $\quad{ }^{75}$ See Athletic News, 8 May igi 6. 
blood sacrifice strengthened the sport's belief in its mission. RFU president Arthur Hartley led the way with his declaration that 'we are proud of the race that give us Rugby football at its best, and we would hold to the fine traditions now handed down to us by the fallen ... Their supreme sacrifice will not have been in vain if we live nobly and carry into the game their spirit. ${ }^{76}$ It is possible to argue that such statements are merely enthusiastic expressions of imperial loyalty. However, by I9I9 RFU spokesmen were freely using the rhetoric of the pre-war glorification of the warrior's death and enthusiastically helping to create what George Mosse has described as a 'cult of the fallen soldier' ${ }^{77}$ Writing in the Rugby football internationals' roll of honour, E. H. D. Sewell declared of the dead: 'there is not one among us who does not envy them for their glorious deaths for King, for Empire and for the Right'. Army chaplain and vice-president of Yorkshire Rugby Union Richard Huggard, who had lost two sons in the war, stated that 'we fathers miss our sons, but we thrill with pride, aye, and joy, when we remember the cause for which our boys died'. Bob Oakes, who organized many of the wartime matches in the north of England, shared similar sentiments. 'We now know how splendidly the Rugby footballer, in common with every British soldier, fought aye, and how magnificently he died!'

Nor can it be argued that those making such statements were ignorant of the realities of war, as can be seen in the most chilling of eulogies to rugby union players, delivered by James Miller, president of the Headingley club in I9I9:

And then, in the rotation of trenches and bullets, came the moment when they had to take their chance 'over the top'. With pulses quickened they waited through the night, their minds filled with the hidden fear, but no regret. For the same spirit possessed them, uplifted them, until, as the dawn rose and the signal was given, it carried them over and on through the blinding showers of lead, until one, then another, and another, and more and yet more then, called to the sacrifice, passed over into the shadows of the 'Beyond'. ${ }^{78}$

Jay Winter has suggested that such rhetoric was largely produced by those too old to fight, yet these sentiments were prevalent throughout rugby union. ${ }^{79}$ Far from being 'devastatingly destroyed by the first experience of bombardment in the trenches' as has been claimed by David Cannadine, the comments of officials such as Miller and players such as Paul Jones demonstrate how deep and resilient was the belief that war was a variant of sport. In the Boy's Own Paper in IgI9 international three-quarter George Hirst wrote of those rugby players killed in the conflict, 'they paid the greatest sacrifice of all; they scored for England, for the world, in the greatest contest the earth has ever known' ${ }^{80}$ Far from viewing the conflict as 'the war to end all wars', the leaders of the RFU emphasized their

76 Torkshire Rugby Football Union commemoration book, p. 272.

77 George Mosse, Fallen soldiers: reshaping the memory of the world wars (Oxford, I990), especially ch. 5.

78 E. H. D. Sewell, The rugby football internationals' roll of honour (London, I9I9), p. I; Yorkshire Rugby Football Union commemoration book, pp. 278, 279, and 276.

79 Winter, Sites of memory, p. 204.

${ }^{80}$ Cannadine, War and death, p. I97; Boy's Own Paper, Nov. I9ı9, p. 42. 
sport's war record as a demonstration of its willingness to go to war again. Sewell declared in the Roll of honour that 'whenever [England] calls again, Rugby Football will be the first to line out; bending forward eager for the moment the fight begin, and ready to "stick it", come what may'. Former RFU secretary Rowland Hill was similarly keen when unveiling Blackheath's war memorial in I92r. 'Generations yet unborn will enter with spirit into the great games of England and will regard their country with such reverence and keen affection that should she ever again need the services of her young men they will be prepared to follow in the footsteps of the illustrious dead. ${ }^{, 81}$

This view of the war adds much weight to the observation by Jeffrey Richards and many others that middle-class disillusionment immediately after the war, exemplified by writers such as Wilfred Owen and Robert Graves, was atypical and confined to small circles of the intelligensia. ${ }^{82}$ The importance of sport to political or social discourse is that it provides an emotional framework based on the simple categories of victory and defeat. Rugby union provided a cultural vehicle through which to express conservative (both in political terms and through its re-assertion of traditional values) patriotic middle-class opinion. It articulated the feelings of those sections of the middle classes for whom victory in the war meant confirmation of the continuing validity of the values of the Edwardian era. The fact that it was a sporting body allowed it to express such thoughts in ostensibly non-political, cultural language.

Its writers tapped into the emotional resonance of the game by mining the same sources as mainstream middle-class opinion, especially through the use of poetry in the traditional styles that had been established by writers such as Newbolt. Rather than being the birth of 'modern memory', as Fussell has argued for high art, the memory of war fashioned by popular middle-class culture was solidly rooted in the past. August IgI 4 witnessed an explosion of patriotic doggerel and for rugby union the use of this 'heroic' style of poetry became almost de rigueur when writing about its experience of war. Both Sewell's Roll of honour and the similar Yorkshire rugby union commemoration book were replete with patriotic poetry ranging in quality from schoolboy musings to Rupert Brooke. Sewell's book began with a call to arms:

Sound, sound the clarion, fill the fife

To all the sensual world proclaim

One crowded hour of glorious life

Is worth an age without a name!

The Yorkshire book was more extensive in its use of poetry. Bob Oakes, Yorkshire Rugby Union secretary, quoted Canadian poet R. W. Service, 'For all our beauty, and hope, and joy/We will owe to our lads like you.' Rowland Hill

${ }^{81}$ Sewell, Roll of honour, p. 3. Rowland Hill speech quoted in McCabe, Rugby and the Great War, p. 44.

82 Jeffrey Richards, 'Popular imperialism and the image of the army in juvenile literature', in J. M. MacKenzie, ed., Popular imperialism and the military, 1850-1950 (Manchester, 1992). 
began his article with the words 'And us they trusted; we the task inherit,/The unfinished task for which their lives were spent.' Arthur Hartley ended his appreciation of the fallen with the words 'In grateful love I bow the knee/For nameless men who died for me.' Perhaps inevitably the portraits of the dead Yorkshire players was prefaced with extracts from Brooke's I9I4, starting with the famous words 'If I should die, think only this of me:/That's there's some corner of a foreign field/That is for ever England.' The phrase 'happy warrior', taken from Wordsworth's I806 poem, was one of the most over-used phrases in writings about players killed in action, especially when referring to Ronald Poulton. 'Amid his peers, a happy warrior sleeps' ended Alfred Ollivant's poem R.W.P.P., killed in the trenches. ${ }^{83}$ Clifton, a club which lost forty-five members, commemorated its lost players with cod-Brooke:

Go search ye o'er the battlefields,

These names will be found again,

Each one inscribed on a cross

To show how they played the game.

They died; a handful of a mighty host

Who gave their lives that you and I

Might live. They died like men in foreign lands,

In the Club they will never die. ${ }^{84}$

Even as late as I925 Brooke was being quoted by Leonard Tosswill in his article on the war for the revised edition of Frank Marshall's Football: the rugby union game. Martin Pugh's observation that 'the Great War proved to be spiritually rewarding for British Conservatives' applies equally to rugby union and its supporters. ${ }^{85}$

Indeed, the most remarkable feature of rugby's use of poetry is not simply the way in which it was used to convey a sense of debt and consequent duty, but also its linking of that debt to the greater corporate glory of rugby union itself. It resembles, perhaps unsurprisingly, the way in which the histories of military regiments or biographies of saints are written. In much of the poetry and prose written, 'England' and 'rugby' are virtually interchangeable; the sport itself is the carrier of the imperial message. 'All's well with England; Poulton's on his game' was a key line in Ollivant's poem. No other sport abrogated to itself such a position: soccer and rugby league certainly did not see themselves in this role and it is patently absurd to imagine a golf or tennis club with similar pretensions. Even cricket, the imperial sport par excellence, was far more restrained and circumspect when discussing the war. ${ }^{\mathbf{8 6}}$

83 Spectator, 22 May i9I5.

${ }^{84}$ F. C. Hawkins and E. Seymour-Bell, Fifty years with the Clifton R.F. C., I872-I922 (Bristol, I922), p. 92.

${ }_{85}$ Martin Pugh, The Tories and the people, I880-I935 (Oxford, I985), p. I75.

${ }^{86}$ For more on cricket and the war see Jack Williams, Cricket and England: a cultural and social history of the inter-war years (London, I999), pp. 6-7. 
The memorials, poetry, commemorations, and the cult of its fallen were the means by which rugby union paid homage to itself as the embodiment of middleclass tradition and stability in a post-war world in which these certainties were being challenged. Fussell has pointed how the literature of the immediate postwar period highlighted 'the persistence of the binary sense and the prevalence of the conception of "the enemy" in British society during this period and this was very strongly reflected in rugby union writings of the time. One only has to look at the alacrity with which the ban on NU players was reinstated in January I9I9 to see that the pre-war social divisions were not only preserved intact by the sport but were pursued with equal, if not greater, vigour. ${ }^{87}$

\section{I I}

It was its record in the war as a defender of Edwardian imperial ideals that laid the basis for the rugby's ousting of soccer as the dominant sport in the public and grammar schools in the I920s. In February I9I9 an unnamed headmaster wrote to The Times to claim that rugby

has proved itself to be unequalled by any other game as a school of true manhood and leadership ... It is all the greater pity that there should still be some great schools that follow the less inspiring and less severe discipline of Association, and a very few that play an esoteric game of their own. Now that all the world is devoting itself to reconstruction, and all institutions are making a new start, is it too much to hope that all schools will consider seriously the adoption of Rugby football as the winter game for all the youth of the nation. ${ }^{88}$

The following week another correspondent pointed to another source of its appeal: 'the way in which all Rugby clubs, aided very fully by the Rugby Union, almost ordered all players to the colours in August I9I4, realising that the game for which they had been preparing for so many years had begun, made a deep impression on the country ${ }^{89}$

Before the war, soccer had been the premier sport of the public schools, although the efforts of the RFU and the link between soccer and working-class professionalism had helped to increase rugby's popularity. By the mid-Igoos a number of schools had begun to take up the rugby game: for example, Eton first started to play the game in $1908 .{ }^{90}$ But rugby's prominence during and after the war provided the impetus for a major shift in the sporting geography of elite schools. Ampleforth, Rossall, City of London, Radley, and Malvern schools, followed by many others, all took up the sport during or immediately after the war. In January I9I9 a campaign began for Winchester to take up rugby led by old boy Brigadier-General Godfrey Meynell, a former commanding officer on the Western Front. Countless other private schools abandoned soccer and opted

${ }^{87}$ Fussell, The Great War, pp. Io9-Io; Times, 3 Mar. I9I9.

88 Times, 26 Feb. I9I9.

89 Ibid., 4 Mar. I9I9.

90 Eton's adoption of rugby is described in the magazine Rugby Football, I6 Feb. I924. 
for rugby in the I920s precisely because of its record during the war. By 1929 , the number of public and grammar schools affiliated to the RFU had more than quadrupled to I33, up from twenty-seven in I9I9. Indeed, such was the rate at which public schools took up the oval-ball game that the beleaguered soccer-playing schools forced a debate on the issue, to little avail, at the 1925 annual meeting of the Headmasters' Conference. ${ }^{91}$ The 'rush to rugby' of the I920s also saw the formation of hundreds of new rugby union clubs for adult males, attracted by the sport's cultural articulation of a 'yearning for pre-war certainties', which others have pointed out was also a feature of newspapers aimed at the middle classes such as the Daily Mail. ${ }^{92}$

English rugby union's attitude to the war contrasted sharply with that of the predominantly working-class rugby league cousin. Once it was over, rugby league barely mentioned the war. A similar attitude existed in soccer. John Osborne's study of Athletic Newes, in many respects the house organ of the Football League, has shown how its attitudes had changed by the end of the war. 'There was no more talk of training players in drill and marksmanship and, in a more impressionistic light, the language of even the match reporting signified war weariness', he noted, pointing to a substantial decline in the use of military metaphors to describe the action on the pitch. ${ }^{93}$ It is also worth noting that one of the strongest surviving symbolic memories of soccer during the war is of informal games played between British and German troops in no man's land during the impromptu truces of Christmas igr4, an image of peace and international brotherhood counterposed to rugby union's militarism. ${ }^{94}$

The war also threw into sharp relief the level of class-consciousness that rugby union's adherents possessed. Tony Mason and Dave Russell have pointed to the phenomenon of a 'consciousness of class but not class-consciousness' among working-class soccer supporters - the same is true of rugby league - but English rugby union displays a much higher level of class-consciousness than almost any other sport. ${ }^{95}$ Throughout the war, it overtly saw itself as a game for the middle classes in opposition to working-class sport and as a cultural adjunct of the officer classes in the military. The experience of rugby suggests that whilst the patriotic fervour of the war years may have temporarily suppressed some of the antagonisms between the classes, the fundamental conflicts still remained, re-emerging almost as soon as the war ended.

\footnotetext{
${ }^{91}$ Figures from RFU handbooks for 1919-20 and 1929-30. For the Headmasters' Conference see Report of the 53rd meeting of the Headmasters' Conference, pp. 33-4, and its Bulletin No. 4 of 1925, p. 28.

${ }^{92}$ Tom Jeffrey and Keith McClelland, 'A world fit to live in: the Daily Mail and the middle classes, I918-I939', in James Curran, Anthony Smith, and Pauline Wingate, eds., Impacts and influences: essays on media power in the twentieth century (London, 1987), p. 42.

${ }^{93}$ John Osborne, 'To keep the life of the nation on the old lines: the Athletic Newes and the First World War', Journal of Sport History, I4 (1987), pp. I37-50, at p. I49.

${ }^{94}$ Whether football was played during the Christmas truces is currently unclear; see Malcolm Brown and Shirley Seaton, in Christmas truce (London, 1994), pp. 134-9.

${ }_{95}$ Tony Mason, Association football and English society, I863-I9I5 (Brighton, I98I); Dave Russell, Football and the English (Aldershot, 1997).
} 
For English rugby union and its supporters, the Great War did not mark the passing of the old world, but a living re-affirmation of the continuing validity of late Victorian and Edwardian ideology in a world where those values appeared to be seriously threatened. It was a heritage that was to remain central to the sport for the rest of the twentieth century. ${ }^{96}$

96 The identification of rugby union with war continues today: for example, Brendan Gallagher, 'Pass masters of battle front', in the Daily Telegraph, 7 Nov. 2001. 